\title{
Viruses in Maize and Johnsongrass in Southern Ohio
}

\author{
L. R. Stewart, R. Teplier, J. C. Todd, M. W. Jones, B. J. Cassone, \\ S. Wijeratne, A. Wijeratne, and M. G. Redinbaugh
}

First, third, fourth, fifth, and eighth authors: U.S. Department of Agriculture, Agricultural Research Services, Corn, Soybean and Wheat Quality Research Unit, Wooster, OH; first and eighth authors: The Ohio State University, Department of Plant Pathology, Wooster; second author: University of Avignon, Avignon, France; and sixth and seventh authors: The Ohio State University, Molecular and Cellular Imaging Center, Wooster.

Accepted for publication 2 June 2014.

\begin{abstract}
Stewart, L. R., Teplier, R., Todd, J. C., Jones, M. W., Cassone, B. J., Wijeratne, S., Wijeratne, A., and Redinbaugh, M. G. 2014. Viruses in maize and Johnsongrass in southern Ohio. Phytopathology 104:13601369.

The two major U.S. maize viruses, Maize dwarf mosaic virus (MDMV) and Maize chlorotic dwarf virus (MCDV), emerged in southern Ohio and surrounding regions in the 1960s and caused significant losses. Planting resistant varieties and changing cultural practices has dramatically reduced virus impact in subsequent decades. Current information on the distribution, diversity, and impact of known and potential U.S. maize

viruses present at the sites of past disease emergence, we used a combination of serological testing and next-generation RNA sequencing approaches. Here, we report enzyme-linked immunosorbent assay and RNA-Seq data from samples collected over 2 years to assess the presence of viruses in cultivated maize and an important weedy reservoir, Johnsongrass (Sorghum halepense). Results revealed a persistent reservoir of MDMV and two strains of MCDV in Ohio Johnsongrass. We identified sequences of several other grass-infecting viruses and confirmed the presence of Wheat mosaic virus in Ohio maize. Together, these results provide important data for managing virus disease in field corn and sweet corn maize crops, and identifying potential future virus threats.
\end{abstract} disease-causing viruses is lacking. To assess the current reservoir of
In the 1960s to 1970s, a high-impact disease complex emerged in the Midwestern and southeastern United States maize (Zea mays L.)-growing regions (23), causing major yield loss. Research on the pathogens resulted in the description of two major maize viruses in the United States: Maize chlorotic dwarf virus (MCDV) and Maize dwarf mosaic virus (MDMV). MCDV and MDMV were originally described in southern Ohio and isolated from lowlands along the Ohio River near Portsmouth, $\mathrm{OH}$ (25,51). Following emergence of these viruses, control strategies were implemented to limit disease losses. Disease management included breeding and planting virus-resistant hybrids. Resistance against MDMV and tolerance against MCDV have been identified (49). Controlling Johnsongrass (Sorghum halepense (L.) Pers.), the major overwintering host of both MDMV and MCDV in the Midwestern and southeastern United States $(23,29)$, is also an effective way to limit virus spread. MDMV is not efficiently seed transmitted (40), and no seed transmission is reported for MCDV; therefore, reducing overwintering virus reservoirs and planting resistant germplasm should result in effective control of the virus.

Following $>40$ years of management of MCDV and MDMV in southern Ohio and surrounding Midwestern and southern U.S. maize growing regions, there have been few reports of major yield losses. Consequently, diseases caused by these viruses have attracted less attention in recent years. The goals of this work

Corresponding author: L. R. Stewart; E-mail address: lucy.stewart@ars.usda.gov

* The $\boldsymbol{e}$-Xtra logo stands for "electronic extra" and indicates that the online version contains two supplemental tables and two supplemental figures. Figure 1 appears in color online.

http://dx.doi.org/10.1094/PHYTO-08-13-0221-R

This article is in the public domain and not copyrightable. It may be freely reprinted with customary crediting of the source. The American Phytopathological Society, 2014. were to (i) ascertain the current status of MCDV and MDMV infection in Ohio, where these viruses were originally isolated, and (ii) identify viruses present in maize and a major virus reservoir (Johnsongrass) by next-generation sequencing to better understand inocula and potential virus disease risks for U.S. maize.

As next-generation sequencing has become more affordable and data analysis has improved, it has become increasingly used for virus identification and discovery $(4,5,7-9,11,14,15,20,31,32$, $43,44,46,50,65-68)$. Although unnecessary for routine diagnosis, we expect this approach to be valuable for periodic evaluation of virus populations and identifying previously undescribed viruses. Understanding the inocula and sequence diversity of viruses currently present in maize growing systems is a valuable component of understanding virus evolution and disease risk management. Populations and sequence variants of prevalent viruses may also be important. For example, a resistance-breaking isolate of MDMV has been reported in Italy (63), although the molecular determinants are not clear. The currently known MCDV isolate sequences $(13,38,47$; Gingery et al., unpublished data) for Type, Severe, Mild, and Tennessee (MCDV-T, MCDV-S, MCDV-M1, and MCDV-Tn) are very diverse, sharing only 56 to $65 \%$ nucleotide identity (57). We hypothesized that other sequences or intermediates could be identified in natural populations. Previously unreported viruses continue to emerge or be discovered; therefore, the possibility of other viruses in maize is also intriguing. The results herein report viruses identified in maize and Johnsongrass collected in Ohio as detected by serology and sequencing over two seasons, 2011 and 2012.

\section{MATERIALS AND METHODS}

Sample collection and processing. Plant samples were collected at various locations in southern Ohio along the Ohio, 
Scioto, and Muskingham River lowlands in May and June 2011 and 2012 (Tables 1 and 2). Samples were collected based on the appearance of potential virus symptoms such as mosaic, chlorosis, vein banding, and other unusual and potentially virus-induced phenotypes (Fig. 1). Asymptomatic samples were also collected at each location. Within the United States collective maize crop, field corn and sweet corn differ substantially in susceptibility to maize viruses, and are referred to herein in these terms for clarity. In 2011, the majority of samples collected were Johnsongrass, with some field corn and sweet corn samples also collected. In 2012, most collected samples were sweet corn. Samples were dug and potted on site or bagged and stored on ice in a cooler for transport and then stored in a cold room $\left(10^{\circ} \mathrm{C}\right)$. Within 1 to 3 days after collection, samples were weighed and frozen at $-80^{\circ} \mathrm{C}$ until processing. Potted plants were kept in greenhouses, treated weekly with insecticides to prevent virus transmission after transport, and maintained indefinitely (Johnsongrass) or until plants senesced (maize). Johnsongrass plants were insecticide treated weekly and cut back approximately monthly with bleach-disinfected shears to avoid cross-infection between plants after collection.

Insect collections and transmissions. At each location, insects were swept and caged for later identification. Insect transmission from Johnsongrass testing positive for MCDV to 'Early Sunglow' maize was performed using laboratory-reared Graminella nigrifrons colonies, as previously described (34). Vascular puncture inoculation (VPI) transmission using collected plant sap was conducted as described before (35) using 'Spirit' maize seed.

Protein A sandwich enzyme-linked immunosorbent assay. Samples were tested for the presence of MCDV and MDMV using protein A sandwich enzyme-linked immunosorbent assay (PAS-ELISA) and in-house antisera: anti-MCDV-T 9010, antiMDMV-A 908, and anti-MDMV-B 905 (to detect Sugarcane mosaic virus [SCMV, formerly known as MDMV-B] ) at dilutions of 1:400, 1:200, and 1:400, respectively. Positive controls within plates were leaves of 'Oh28' maize infected with Ohio isolates of each virus $(21,24,36)$. Sample tissue ground at 1:5 (wt/vol) in phosphate-buffered saline $\left(0.02 \mathrm{M} \mathrm{NaPO}_{4}\right.$ and $\left.0.15 \mathrm{M} \mathrm{NaCl}\right), 2 \%$

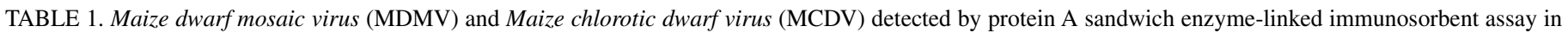
maize and Johnsongrass collected in 2011

\begin{tabular}{|c|c|c|c|c|c|c|c|c|c|c|c|}
\hline \multirow[b]{2}{*}{ Code $^{a}$} & \multirow[b]{2}{*}{ County } & \multicolumn{2}{|c|}{ Insects trapped ${ }^{b}$} & \multicolumn{2}{|c|}{ Johnsongrass } & \multicolumn{2}{|c|}{ Sweet corn } & \multicolumn{2}{|c|}{ Field corn } & \multirow[b]{2}{*}{ Samples $^{\mathrm{c}}$} & \multirow[b]{2}{*}{ Total $^{\mathrm{d}}$} \\
\hline & & A & G & MDMV & MCDV & MDMV & MCDV & MDMV & MCDV & & \\
\hline A & Pickaway & - & + & $0 / 1$ & $0 / 1$ & 0 & 0 & $0 / 1$ & $0 / 1$ & 2 & 0 \\
\hline B & Pickaway & - & - & $0 / 5$ & $0 / 5$ & 0 & 0 & $0 / 1$ & $0 / 1$ & 6 & 0 \\
\hline $\mathrm{C}$ & Pickaway & - & - & $4 / 6$ & $0 / 6$ & 0 & 0 & $1 / 2$ & $0 / 2$ & 8 & 0 \\
\hline $\mathrm{D}$ & Pickaway & - & - & $5 / 8$ & $0 / 8$ & $2 / 2$ & $0 / 2$ & 0 & 0 & 10 & 0 \\
\hline $\mathrm{E}$ & Ross & - & - & $2 / 4$ & $1 / 4$ & 0 & 0 & 0 & 0 & 4 & 1 \\
\hline $\mathrm{F}$ & Ross & - & + & $0 / 2$ & $0 / 2$ & 0 & 0 & $0 / 1$ & $0 / 1$ & 3 & 0 \\
\hline $\mathrm{F}$ & Scioto & - & + & $4 / 11$ & $9 / 11$ & 0 & 0 & $0 / 1$ & $0 / 1$ & 12 & 4 \\
\hline $\mathrm{G}$ & Scioto & - & - & $1 / 8$ & $2 / 8$ & $2 / 5$ & $1 / 5$ & 0 & 0 & 13 & 0 \\
\hline $\mathrm{H}$ & Washington & + & - & $3 / 3$ & $0 / 3$ & $6 / 7$ & $0 / 7$ & 0 & 0 & 10 & 0 \\
\hline I & Washington & - & - & $7 / 7$ & $2 / 7$ & $3 / 3$ & $0 / 3$ & 0 & 0 & 10 & 2 \\
\hline $\mathrm{J}$ & Washington & - & - & 0 & 0 & 0 & 0 & $0 / 3$ & $0 / 3$ & 3 & 0 \\
\hline $\mathrm{K}$ & Meigs & - & + & $3 / 5$ & $0 / 5$ & $2 / 5$ & $0 / 5$ & 0 & 0 & 10 & 0 \\
\hline $\mathrm{L}$ & Meigs & - & - & $1 / 2$ & $1 / 2$ & 0 & 0 & 0 & 0 & 2 & 0 \\
\hline M & Meigs & - & - & $1 / 6$ & $1 / 6$ & $0 / 4$ & $0 / 4$ & 0 & 0 & 10 & 0 \\
\hline $\mathrm{N}$ & Meigs & - & - & $1 / 4$ & $1 / 4$ & 0 & 0 & 0 & 0 & 4 & 0 \\
\hline $\mathrm{O}$ & Meigs & - & + & $2 / 4$ & $4 / 4$ & 0 & 0 & 0 & 0 & 4 & 2 \\
\hline $\mathrm{P}$ & Washington & - & - & $6 / 6$ & $5 / 6$ & 0 & 0 & $2 / 2$ & $1 / 2$ & 8 & 6 \\
\hline Total & $\ldots$ & $\ldots$ & $\ldots$ & $40 / 82$ & $26 / 82$ & $15 / 26$ & $1 / 26$ & $3 / 11$ & $1 / 11$ & 119 & 15 \\
\hline
\end{tabular}

a Two county locations were labeled with code $\mathrm{F}$.

b $\mathrm{A}=$ aphids, $\mathrm{G}=$ Graminella,$+=$ insects found, and $-=$ no insects found.

c Samples per location.

d Total co-infected.

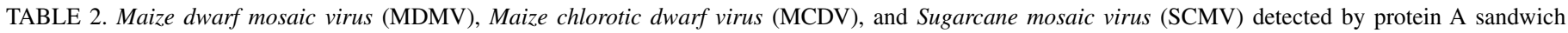
enzyme-linked immunosorbent assay in maize and Johnsongrass collected in 2012

\begin{tabular}{|c|c|c|c|c|c|c|c|c|c|c|c|}
\hline \multirow[b]{2}{*}{ Code } & \multirow[b]{2}{*}{ County } & \multicolumn{2}{|c|}{ Insects trapped ${ }^{a}$} & \multicolumn{3}{|c|}{ Johnsongrass } & \multicolumn{3}{|c|}{ Sweet corn } & \multirow[b]{2}{*}{ Samples ${ }^{\mathrm{b}}$} & \multirow[b]{2}{*}{ Total $^{c}$} \\
\hline & & A & $\mathrm{G}$ & MDMV & MCDV & SCMV & MDMV & MCDV & SCMV & & \\
\hline AA & Pickaway & - & - & $0 / 1$ & $0 / 1$ & $0 / 1$ & $\mathrm{NS}^{\mathrm{d}}$ & NS & NS & 1 & 0 \\
\hline BB & Pickaway & - & - & $0 / 1$ & $0 / 1$ & $0 / 1$ & $0 / 3$ & $0 / 3$ & $0 / 3$ & 4 & 0 \\
\hline $\mathrm{CC}$ & Pickaway & - & + & $2 / 2$ & $1 / 2$ & $1 / 2$ & $3 / 3$ & $0 / 3$ & $1 / 3$ & 5 & 1 \\
\hline DD & Pike & - & - & $1 / 1$ & $1 / 1$ & $0 / 1$ & NS & NS & NS & 1 & 1 \\
\hline $\mathrm{EE}$ & Pike & - & + & $1 / 1$ & $1 / 1$ & $0 / 1$ & $2 / 3$ & $0 / 3$ & $0 / 3$ & 4 & 1 \\
\hline FF & Scioto & - & + & $5 / 8$ & $0 / 8$ & $0 / 8$ & $\mathrm{NS}$ & NS & NS & 8 & 0 \\
\hline GG & Scioto & + & - & NS & NS & NS & $4 / 9$ & $0 / 9$ & $0 / 9$ & 9 & 0 \\
\hline $\mathrm{HH}$ & Scioto & + & + & $3 / 5$ & $2 / 5$ & $0 / 5$ & $4 / 5$ & $1 / 5$ & $1 / 5$ & 10 & 3 \\
\hline II & Scioto & + & - & $1 / 1$ & $1 / 1$ & $0 / 1$ & $7 / 7$ & $0 / 7$ & $0 / 7$ & 8 & 1 \\
\hline $\mathrm{JJ}$ & Washington & + & - & $3 / 3$ & $1 / 3$ & $0 / 3$ & $8 / 8$ & $0 / 8$ & $0 / 8$ & 11 & 0 \\
\hline KK & Washington & - & + & $1 / 2$ & $0 / 2$ & $0 / 2$ & $9 / 9$ & $0 / 9$ & $0 / 9$ & 11 & 0 \\
\hline $\mathrm{LL}$ & Washington & - & - & $0 / 2$ & $0 / 2$ & $0 / 2$ & NS & NS & NS & 2 & 0 \\
\hline MM & Meigs & - & + & $2 / 3$ & $0 / 3$ & $0 / 3$ & $6 / 7$ & $0 / 7$ & $0 / 7$ & 10 & 0 \\
\hline $\mathrm{NN}$ & Meigs & - & + & $1 / 3$ & $1 / 3$ & $0 / 3$ & $0 / 2$ & $0 / 2$ & $0 / 2$ & 5 & 1 \\
\hline Total infected & $\ldots$ & $\ldots$ & $\ldots$ & $20 / 33$ & $8 / 33$ & $1 / 33$ & $43 / 56$ & $1 / 56$ & $2 / 56$ & 89 & 8 \\
\hline
\end{tabular}

a $\mathrm{A}=$ aphids, $\mathrm{G}=$ Graminella,$+=$ insects found, and $-=$ no insects found.

b Samples per location.

c MCDV/MDMV co-infected.

${ }^{\mathrm{d}} \mathrm{NS}=$ no samples; no symptoms were observed at location. 


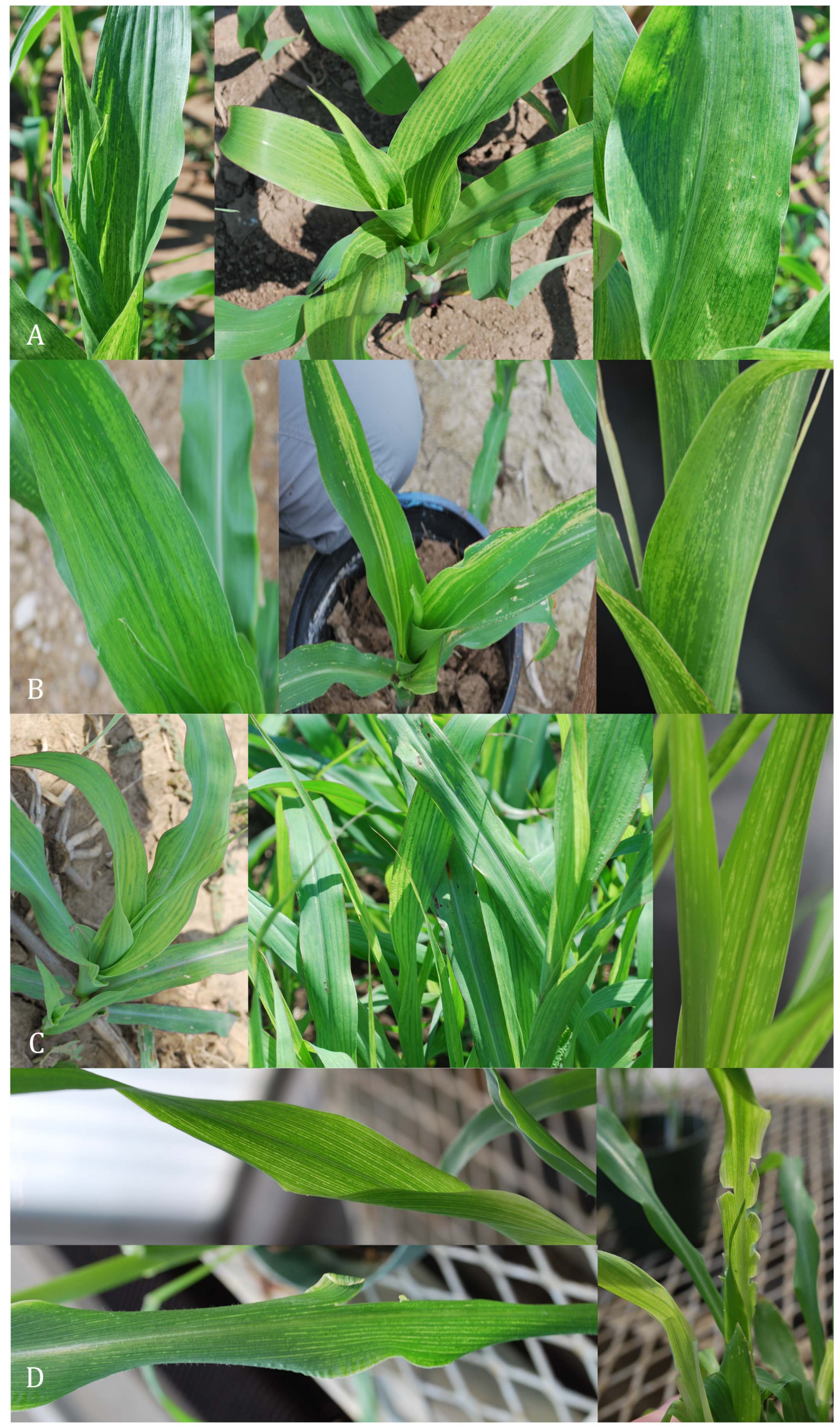

Fig. 1. Virus-like symptoms. A, General mosaic on sweet corn; B, streaked mosaic symptoms on plant with Wheat mosaic virus (WMoV); C, mosaic and ringspotting on Johnsongrass; and D, vein clearing and twist and tear on sweet corn plants inoculated with Maize chlorotic dwarf virus (MCDV) from fieldcollected Johnsongrass. 
polyvinylpyrrolidone, and $0.2 \%$ bovine serum albumin was used for PAS-ELISA (16). Leaves from two healthy Oh28 maize plants were included in each plate as negative controls. Each sample tested was plated in duplicate for ELISA.

Samples were scored as positive in PAS-ELISA if averaged sample values exceeded two or more of three cutoffs: sample absorbance at $405 \mathrm{~nm}>$ mean negative control absorbance plus three times the standard deviation of the negative controls, increase in sample absorbance at $405 \mathrm{~nm}>$ twice the slope of the negative controls, and sample absorbance at $405 \mathrm{~nm}>$ twice the average absorbance of within-plate negative control readings. Cutoff parameters were selected empirically (60).

RNA-Seq: Sample preparation and sequencing. Total RNA was extracted from fresh or frozen tissue using a DirectZol kit, according to the manufacturer's instructions (Zymo Research, Irvine, CA). RNA quantity and quality were determined using the Experion Automated Electrophoresis System (Bio-Rad, Hercules, CA). Only samples with RNA quality indicator values $\geq 7$ were selected for cDNA synthesis. Two pooled samples were sequenced: one from 20 Johnsongrass plants collected in 2011, and one from 24 maize plants collected in 2012. Pooled Johnsongrass leaves were from plants coded A1, B4, C4, C5, D2, E1, F4, F11, F13, F15, F16, G1, G13, H2, I2, K3, L1, L2, M1, and N1. Pooled maize leaves were from plants coded CC1, EE1, GG1-3, GG5, GG6-8, HH1-3, II1-3, JJ1-2, KK1-3, LL1, and MM1-3 according to plant number and collection locations (Tables 1 and 2).

Total RNA $(1 \mu \mathrm{g})$ was used to generate adaptor-ligated doublestranded cDNA libraries for RNA-Seq using the TruSeq Sample Prep Kit V1 and V2 (Illumina, San Diego, CA), following the manufacturer's protocol. Polyadenylated RNA was selected from total RNA by binding to poly(T) oligonucleotide-attached magnetic beads and used as template for cDNA synthesis. Quantification of ds-cDNA was carried out using the Qubit 2.0 Fluorometer (Life Technologies, Carlsbad, CA) and quality was assessed using the Experion Automated Electrophoresis System (Bio-Rad). Samples were diluted to $17.5 \mathrm{nM}$ based on calculated average fragment size, then pooled to generate the multiplexed cDNA library.

The cDNA library (35 fmol) was sequenced on one flow-cell lane using the Illumina HiSeq 2000 platform at the Ohio State University Comprehensive Cancer Center. The mean library insert sequence size was $265 \mathrm{bp}$ and both ends of the library were sequenced to generate 100-bp raw paired-end reads. The Illumina Analysis Package CASAVA 1.8.2 was used to perform bcl conversion and demultiplexing. Image deconvolution and quality value calculations were carried out using the Illumina GA pipeline v1.8.2. Raw reads are deposited in GenBank SRA, accession numbers SAMN02296901 (maize) and SAMN02296902 (Johnsongrass).

RNA-Seq analysis. Samples were analyzed using CLC Genomics (v. 5.5.1; CLC Bio, Cambridge, MA). Demultiplexed reads were trimmed for quality and removal of poly (A) tails and adaptor sequences. Duplicates were removed and sequences were assembled de novo in CLC Bio. Assembled contigs were searched against the National Center for Biotechnology Information (NCBI) nonredundant virus database in CLC Genomics using the tblastx algorithm (10). Potential plant virus sequences were filtered using an E-value cutoff of $10^{-5}$ and a hit length of $<175$ nucleotides (nt), then sorting by top hit descriptions for plant virus matches. Selected contigs were subjected to megablastn against the NCBI nr database. Contigs with top hits to plant sequences (usually maize or sorghum) were removed from further analysis. Remaining contigs were further analyzed, including splitting contigs when paired reads were assembled with $\mathrm{N}_{\mathrm{n}}$ gaps, and manually assembled in Sequencher (v. 4.10.1; GeneCodes Corp., Ann Arbor, MI) to generate contigs of contigs (termed "supercontigs" here) and align to reference virus sequences.
Reverse-transcriptase polymerase chain reaction. RNA samples used for RNA-Seq were also used for reverse-transcriptase polymerase chain reaction (RT-PCR) to confirm the presence of viruses. One-step RT-PCR was performed using 50 to $100 \mathrm{ng}$ of template RNA in a $12.5-\mu \mathrm{l}$ Go-Taq (Promega Corp., Madison, WI) reaction based on manufacturer's protocols. RT-PCR cycle parameters were $50^{\circ} \mathrm{C}$ for $60 \mathrm{~min} ; 94^{\circ} \mathrm{C}$ for $2 \mathrm{~min}$; and 35 cycles at $94^{\circ} \mathrm{C}$ for $30 \mathrm{~s}$, variable annealing temperatures for $30 \mathrm{~s}$, and variable $72^{\circ} \mathrm{C}$ extension times. Primers and amplification parameters are listed in Supplemental Table 1. MCMV primers were designed to amplify sequences conserved in the MCMV-NE, KS, and Yunnan China isolates. RT-PCR to detect Wheat mosaic virus (WMoV) nucleoprotein (NP)-coding RNA was performed as previously described (59) using Access RT-PCR kits (Promega Corp.) on both pooled RNA and RNA from individual plants to identify GG1 as the only WMoV-infected plant. Potyvirus and partitivirus RT-PCRs were performed on pooled RNA-Seq RNA samples. Amplified WMoV, MDMV, and partitivirus products were Sanger sequenced at the Ohio State University PlantMicrobe Genomics Facility. Sequences were analyzed using Sequencher 5.1 (GeneCodes Corp.) and MacVector 12.7.5 (MacVector, Inc., Cary, NC).

\section{RESULTS}

Symptoms in the field. To determine whether virus inoculum was still present at sites where MCDV and MDMV incidence was high in the past, maize and Johnsongrass plants were selected in 2011 and 2012 for various virus-like symptoms, including reddening, yellowing, stunting, mosaic (characteristic of MDMV and other maize-infecting potyviruses), and vein banding (characteristic of MCDV infection) (Fig. 1). Virus-like symptoms were rarely observed in field corn. Sweet corn hybrids were expected and observed to be more susceptible overall (28); thus, sampling focused on sweet corn and adjacent Johnsongrass. Mosaic symptoms were observed on Johnsongrass, sweet corn, and occasionally on field corn (Fig. 1). Mosaic incidence estimated from transects of 12 sweet corn fields varied from 0 to $44 \%$ (data not shown). We did not observe distinct vein-banding symptoms in field plants.

ELISA detection. In-house antisera were tested for PASELISA detection of laboratory-maintained isolates of viruses MDMV OH, SCMV OH, MCDV-T, MCDV-S, and MCDV-M1 prior to testing field-collected samples. MCDV-T antiserum detected all lab isolates MCDV-T, MCDV-S, and MCDV-M1 (data not shown). However, MCDV-T antiserum only detected two-thirds of MCDV-M1 symptomatic plants. MDMV-A antiserum was less sensitive than MCDV antisera, detecting, on average, two-thirds of symptomatic MDMV OH-2 control plants. We consistently observed that this antiserum failed to detect virus in some greenhouse-grown MDMV OH-2 control plants, even though they were symptomatic and had infectious sap (data not shown). SCMV antisera detected only one-third of symptomatic greenhouse-inoculated plants. We observed no cross-reactivity of SCMV antisera with MDMV OH-2 infected plants, or of MDMV antisera with SCMV OH infected plants.

In 2011, 119 samples were collected from 17 locations across five Ohio counties. Of these samples, 11 were from field corn, 26 from sweet corn, and 82 from Johnsongrass. MDMV was detected in 58 samples, while MCDV was detected in 28 (Table 1). Johnsongrass plants testing positive for MCDV by ELISA were further tested by RT-PCR, which detected MCDV sequences similar to MCDV-M1 and MCDV-T (data not shown). In 2012, 95 samples were collected: 33 from Johnsongrass, 56 from sweet corn, and 6 from field corn. MDMV was detected in 66 samples, including 3 of 6 field corn samples from location LL (data not shown). MCDV was detected in nine samples. Two Johnsongrass samples and one sweet corn sample tested positive for SCMV in 
2012 (Table 2). The 2011 samples were not tested for SCMV. Potential insect vectors were detected in some locations in both years (Tables 1 and 2) but populations were not high at sampling times (data not shown).

Nine plants from 2012 sweet corn collections (locations CC, EE, GG, HH, II, JJ KK, LL, and MM) were tested for infectivity by rub inoculating plant sap onto test hosts. A mosaicproducing pathogen with host range similar to MDMV $\mathrm{OH}$ was transmitted from all samples except GG1 (Supplemental Table 2). MCDV was transmitted from Johnsongrass sap testing positive for both MDMV and MCDV using G. nigrifrons as well as VPI. Although MCDV symptoms were not clearly observed in Johnsongrass, very strong diagnostic vein-banding symptoms were observed in the first transmission to maize (Fig. 1D); however, symptoms attenuated after the first 2 weeks postinoculation (not shown).

RNA-Seq on maize and Johnsongrass samples. Subsets of samples collected (20 Johnsongrass plants collected in 2011 and 24 maize plants collected in 2012) were subjected to RNA-Seq to characterize the virus populations present, including sequence diversity of known virus species and identification of viruses not detected by limited serological tests. In total, 2,217,576 raw reads for maize and 29,385,972 raw reads for Johnsongrass were obtained. After removal of poor-quality and duplicate reads, $1,926,284$ and $24,810,868$ reads for maize and Johnsongrass, respectively, were assembled de novo, resulting in assembly of 20,055 maize contigs with average length of $467 \mathrm{nt}$ and 42,964 Johnsongrass contigs with average length of 775 nt. Putative virus sequences were identified as described (Table 3). In total, 39 and 78 contigs of potential virus origin were identified for maize and Johnsongrass, respectively.

MCDV sequences in maize and Johnsongrass. MCDV contigs were not found in the maize samples pooled for RNA-Seq. MCDV contigs identified in Johnsongrass joined into two supercontigs that were near-complete genome sequences for MCDV-T and MCDV-M1 (GenBank accession numbers NC003626 and AY82112, respectively). Contig $(187+6342)$ had 53 nucleotide differences and five gaps relative to the complete MCDV-T sequence. Contig 166 matched MCDV-M1 with three gaps and 97\% identity. Three additional contigs matched MCDV-M1, but with sequence polymorphisms relative to contig 166 . These contigs ranged from 283-1474 nt in length and had 92 to $94 \%$ identity to MCDV-M1 (Fig. 2). Of reads mapping to viruses, 0.04 and $2.4 \%$ from maize and Johnsongrass, respectively, mapped to the three MCDV reference sequences with a 0.5 length fraction and 0.8 similarity fraction (Table 4 ). Of reads mapping to any of three MCDV reference sequences (MCDV-T, MCDV-M1, and MCDV-Tn), $97 \%$ mapped to MCDV-M1.
MDMV sequences in maize and Johnsongrass. MDMV sequences were the most abundant viral sequences identified, assembling into 31 of the 39 putative viral contigs from maize and 50 of 78 from Johnsongrass. In all, $11 \%$ of total maize nonredundant reads $(202,404$ of $1,926,284)$ and $15 \%$ of total Johnsongrass nonredundant reads $(3,699,987$ of $24,810,686)$ mapped to the MDMV OH-1 (58) reference sequence (GenBank accession number JQ403608) with a similarity fraction of at least 0.8 (Table 4). The mapped reads accounted for 94.5 and $92.9 \%$ of putative virus reads from maize and Johnsongrass, respectively. Despite the abundance of MDMV-like sequences covering most of the genome (Fig. 2A; Supplemental Figure 1), no complete MDMV genome sequences were assembled from either plant host, and attempted assemblies of RNA-Seq contigs using $20 \%$ minimum overlap and $95 \%$ identity also resulted in no contigs above $2.3 \mathrm{~kb}$. Review of sequence alignment indicated that a population of polymorphic MDMV sequences was present. Johnsongrass MDMV contigs were between 84 and $100 \%$ identical to the sequenced Ohio isolate MDMV OH-1 (58), with a mean identity of $92 \%$ and a continuum of percent identities to this sequence. Maize MDMV contigs were between 85 and $98 \%$ identical to MDMV OH-1, also with a continuum of identities and a mean identity of $91 \%$.

To better compare MDMV diversity in our samples, we amplified, cloned, and sequenced 10 and 8 complete coat protein (CP) sequences from maize and Johnsongrass pooled RNA, respectively. Cloned CP sequences showed limited polymorphism, with $78 / 912$ polymorphic/total nucleotides and 19/304 polymorphic/ total amino acids across the coding sequence (Supplemental Figure 2). Within the 18 sequences, only two amino acids were polymorphic in more than one clone. Unexpectedly, in contrast to the laboratory-maintained Portsmouth isolate MDMV OH-1, which has a 19-codon deletion in the $\mathrm{N}$ terminus of the $\mathrm{CP}$ relative to European MDMV isolates (58), none of the cloned sequences or RNA-Seq contigs contained this deletion. Rather, the field sample CP sequences all contained a 13-codon insertion relative to most other sequenced isolates, previously reported only in Hungarian MDMV isolates (45,62).

SCMV sequences in maize and Johnsongrass. Contigs with top tblastx and megablastn hits to SCMV sequences were found in both maize and Johnsongrass datasets. Because SCMV was reported as a non-Johnsongrass-infecting potyvirus $(26,53)$, sequence identities of the individual contigs were examined. Three SCMV-like contigs were identified from maize. Two were most similar to SCMV OH (85 to 93\% identity) and one was $98 \%$ identical to SCMV BD8, a virulent Chinese SCMV isolate that is an outgroup compared with other complete SCMV sequences (17). Of 11 Johnsongrass SCMV-like contigs, 4 were most similar to SCMV OH, with sequence identities between 85 and $92 \%$.

TABLE 3. Summary of viruses detected by RNA-Seq ${ }^{a}$

\begin{tabular}{|c|c|c|c|c|c|}
\hline Virus & Contigs & Mean contig length (nt) & Mean tblastx hit length (nt) & Reads (hits) & Virus reads $(\%)$ \\
\hline \multicolumn{6}{|l|}{ Maize } \\
\hline MDMV (all) & 31 & 945 & 721 & 16,623 & 90.6 \\
\hline MCDV (all) & 0 & NA & NA & NA & 0 \\
\hline Emaravirus & 4 & 569 & 426 & 315 & 1.7 \\
\hline SCMV & 3 & 398 & 397 & 1,092 & 6.0 \\
\hline SrMV & 1 & 274 & 273 & 315 & 1.7 \\
\hline Total & 39 & $\ldots$ & $\ldots$ & 18,345 & $\ldots$ \\
\hline \multicolumn{6}{|l|}{ Johnsongrass } \\
\hline MDMV (all) & 50 & 663 & 480 & 21,728 & 70.6 \\
\hline MCDV (all) & 6 & 4,479 & 1,547 & 2,409 & 7.8 \\
\hline SCMV & 12 & 394 & 347 & 4,598 & 14.9 \\
\hline SrMV & 3 & 318 & 296 & 1,071 & 3.5 \\
\hline MCMV & 1 & 303 & 303 & 228 & 0.7 \\
\hline Cryptic virus & 1 & 1,580 & 1,491 & 283 & 0.9 \\
\hline Other & 5 & 348 & 322 & 476 & 1.5 \\
\hline Total & 78 & $\ldots$ & $\ldots$ & 30,793 & $\ldots$ \\
\hline
\end{tabular}

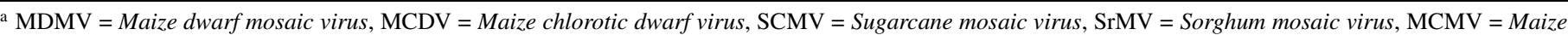
chlorotic mottle virus, $\mathrm{nt}=$ nucleotides, and $\mathrm{NA}=$ not available. 
Seven were most similar to SCMV-BD8, with sequence identities between 92 and 99\%. SCMV-like contigs mapped across the genome when assembled to reference sequences (Fig. 2C). SCMV $\mathrm{OH}$ is 79 and $89 \%$ identical to SCMV BD8 nucleotide and amino acid sequences, respectively, and has a gap relative to SCMV $\mathrm{BD} 8$ at the $\mathrm{N}$ terminus of the CP sequence. Although PAS-ELISA also detected SCMV in three plants, efforts to confirm SCMV RNA in plants by RT-PCR using various primer pairs designed against contigs and conserved CP sequences were unsuccessful.

Sorghum mosaic virus sequences in maize and Johnsongrass. Sorghum mosaic virus (SrMV) sequences were identified in both maize and Johnsongrass (one and three contigs, respectively). These contigs were 230 to 341 nt and matched
SrMV-H (GenBank accession number U57358) (69) at nucleotides 1,503 to $1,741,4,316$ to 4,656 , and 7,239 to 7,613 with 93 to $99 \%$ identity and matched MDMV sequences with $\leq 82 \%$ identity. Of reads mapping to a set of virus reference sequences (Table 4), 0.84 and $0.30 \%$ from maize and Johnsongrass samples, respectively, mapped to SrMV-H at a 0.90 similarity fraction. RT-PCR assays for SrMV CP sequences resulted in no amplification products.

Emaravirus sequences in maize and Johnsongrass. Sequences matching WMoV, also referred to as Maize red stripe virus and High Plains virus in the literature (55), were identified in maize. Based on RT-PCR for a segment of the WMoV NP coding sequence, a single sweet corn plant from Scioto County

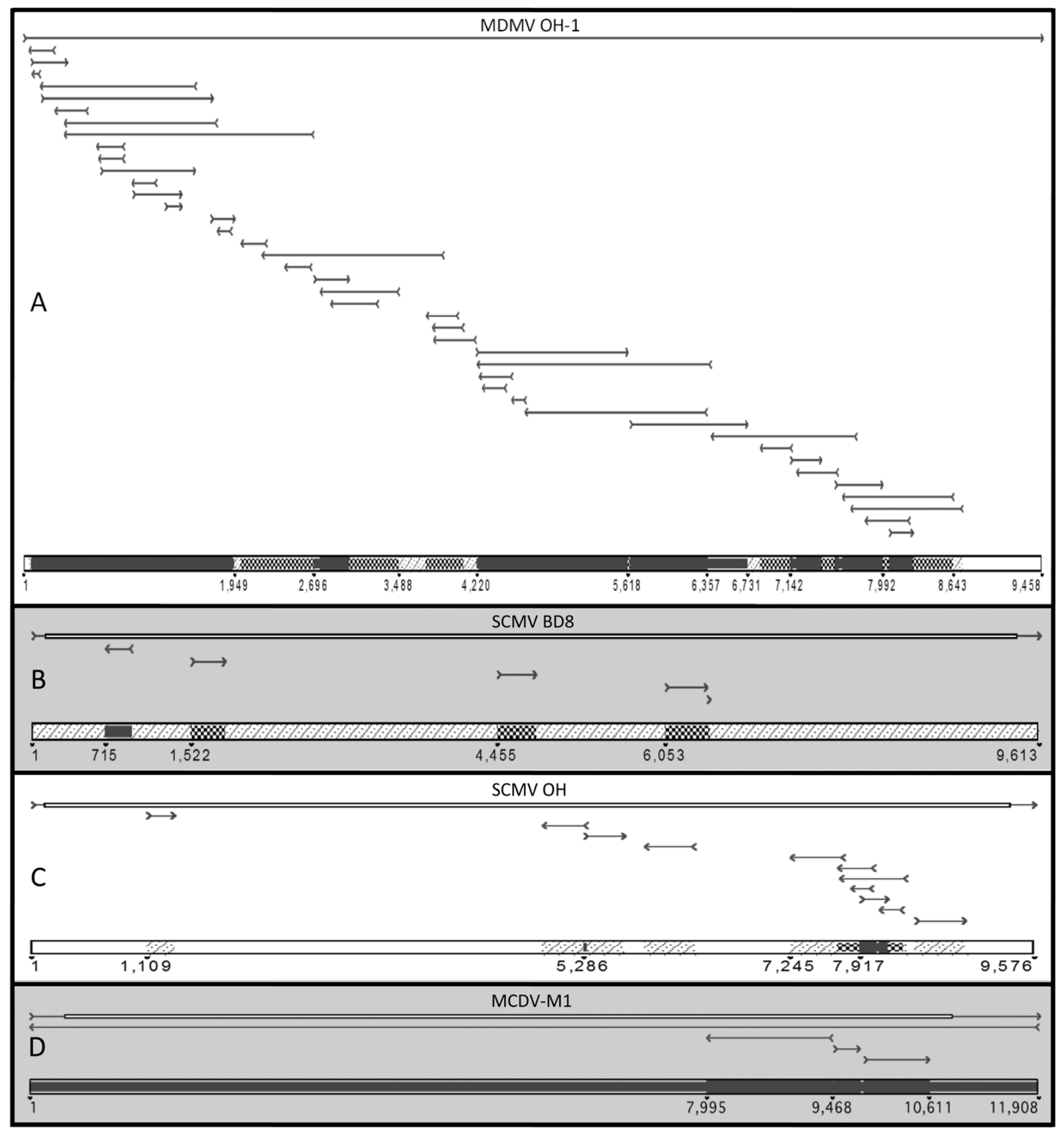

Fig. 2. Mapping de novo assembled contigs to virus reference sequences. A, Maize contigs mapping to MDMV OH-1; and Johnsongrass and maize contigs mapping to $\mathbf{B}$, SCMV-BD8; C, SCMV-OH; and D, MCDV-M1. 
was infected with $\mathrm{WMoV}$, matching its nontransmission by rub inoculation and high-contrast mosaic compared with that caused by MDMV (Fig. 1B). In addition to the sequenced NP-encoding segment of WMoV, we identified additional emaravirus-like sequences in our samples (Table 3 ).

Maize chlorotic mottle virus sequence in Johnsongrass. A single 303-nt contig was $99 \%$ identical to nucleotides 2,132 to 2,434 of MCMV isolate Sichuan from China (GenBank accession JQ982470.1) and 97\% identical to the Nebraska isolate of MCMV (GenBank accession EU358605). Only 0.004\% of nonredundant reads mapped to MCMV at a $95 \%$ similarity fraction (Table 4). RT-PCR on Johnsongrass samples using two primer pairs designed to amplify genome regions conserved in both MCMV NE and MCMV Si outside of the contig region failed to detect MCMV RNA in pooled Johnsongrass RNA-Seq template RNA.

Putative Partitiviridae sequences in Johnsongrass. A novel sequence similar to deltapartitiviruses was identified in Johnsongrass but not maize. Only the RNA-dependent RNA polymerase (RdRP) sequence was found for this bipartite cryptic virus in the selected contig set, with a top megablastn hit to the Pepper cryptic virus 1 RdRP gene (GenBank accession DQ361008), which the 1,580 -nt contig matched with $60 \%$ coverage and $72 \%$ identity. The top tblastx hit for this contig in the NCBI virus database was Raphanus sativus cryptic virus 3 segment 1 (GenBank accession FJ461349), with 60\% coverage and $72 \%$ nucleotide sequence identity. Under the hit length size-selection cutoff, another contig was identified matching a CP-encoding virus segment. This 908-nt contig had $98 \%$ identity to a hypothetical sorghum $(S$. bicolor) mRNA sequence (GenBank accession XM 002465884), with $94 \%$ coverage and $98 \%$ identity, and was also similar to sequences from maize, wheat, and rice, with no blastn hits to known viruses. Tblastx of this contig against the NCBI virus sequence database yielded a top hit to Beet cryptic virus $1 \mathrm{CP}$ gene (GenBank accession EU489062) but with a hit length of only 156. Tblastx of this contig against the entire $\mathrm{nr}$ database did not retrieve cryptic virus sequences. RT-PCR using primers designed against putative cryptic virus contigs yielded a product with sequence identical to the RdRP contig but not the putative $\mathrm{CP}$ sequence.

Other sequences. Sequences that had significant hits in the virus database and survived cutoffs but had no significant matches to the viruses listed above were included in the "other" category. For maize, no sequences were designated "other". However, one contig (contig 12311) appeared to be a misassembly of both maize mRNA and MDMV sequences. Of the 78 Johnsongrass virus-like contigs, 5 did not match any of the above viruses. These matched badnavirus pararetrovirus reverse transcriptase/RNase $\mathrm{H}$ sequences by tblastx to the virus database. Discontiguous megablastn of these sequences against the entire nr database identified Ty3/gypsy retrotransposon matches for all five.

\section{DISCUSSION}

Virus diseases of maize have been very destructive in the United States in the past but are currently well managed. Here, we used both serological assays and RNA sequencing to assess current virus populations in southern Ohio maize (field corn and sweet corn) and the important overwintering virus host, Johnsongrass. Our results show that, after several decades of management, two major U.S. maize viruses, MCDV and MDMV, are still prevalent in Ohio Johnsongrass. Despite improved weed control and the availability of resistant field corn and sweet corn hybrids $(28,48,49)$, inoculum levels were sufficient to observe ubiquitous mosaic in susceptible sweet corn. However, disease was rarely observed in field corn, even in plots adjacent to heavily infected sweet corn. As determined by both ELISA and RNA sequencing, MDMV was by far the most abundant virus in sampled plants,

TABLE 4. Mapping processed, unassembled reads to virus reference sequences

\begin{tabular}{|c|c|c|c|c|c|c|c|}
\hline \multirow[b]{3}{*}{ REFSEQ $^{a}$} & \multirow[b]{3}{*}{ Accession } & \multicolumn{6}{|c|}{ Similarity fraction } \\
\hline & & \multicolumn{3}{|c|}{ Maize } & \multicolumn{3}{|c|}{ Johnsongrass } \\
\hline & & 0.8 & 0.9 & 0.95 & 0.8 & 0.9 & 0.95 \\
\hline MDMV OH & JQ403608 & 202,404 & 195,794 & 116,514 & $3,699,987$ & $3,579,246$ & $2,150,345$ \\
\hline SCMV OH & JX188385 & 3,173 & 2,024 & 974 & 45,850 & 29,476 & 13,538 \\
\hline SCMV BD8 & JN021933 & 2,001 & 693 & 174 & 37,128 & 11,096 & 1,374 \\
\hline SrMV H & U57358 & 4,234 & 1,698 & 223 & 70,626 & 30,029 & 2,579 \\
\hline $\mathrm{JGMV}^{\mathrm{b}}$ & NC003606.1 & 18 & 1 & 0 & 2,144 & 243 & 51 \\
\hline PenMV & NC007147.1 & 1,841 & 451 & 111 & 22,251 & 8,364 & 3,218 \\
\hline HoMV $^{b}$ & NC005904 & 29 & 6 & 0 & 647 & 80 & 45 \\
\hline PVY OH ${ }^{b}$ & AB714134 & 181 & 32 & 2 & 4,990 & 947 & 101 \\
\hline MCDV-T & NC003626.1 & 38 & 7 & 1 & 680 & 69 & 35 \\
\hline MCDV M1 & AY829112.1 & 35 & 14 & 12 & 91,390 & 84,567 & 82,877 \\
\hline MCDV-Tn & U67839 & 13 & 1 & 0 & 2,236 & 254 & 42 \\
\hline HPV NP & DQ324466 & 49 & 27 & 14 & 38 & 1 & 0 \\
\hline MCMV Si & JQ982470 & 40 & 30 & 30 & 199 & 91 & 87 \\
\hline MCMV NE & EU358605 & 12 & 6 & 6 & 95 & 13 & 7 \\
\hline PBV RTase & Y12433.1 & 1 & 0 & 0 & 22 & 0 & 0 \\
\hline $\mathrm{RsCV}-3$ & FJ461349 & 11 & 1 & 1 & 107 & 21 & 0 \\
\hline BCV RNA1 & EU489062 & 50 & 8 & 2 & 397 & 63 & 20 \\
\hline MSV-A ${ }^{b}$ & NC001346.1 & 5 & 0 & 0 & 329 & 23 & 0 \\
\hline Mapped reads & $\ldots$ & 214,135 & 200,793 & 118,064 & $3,979,116$ & $3,744,583$ & $2,254,319$ \\
\hline Mapping to viruses & $\ldots$ & 11.12 & 10.42 & 6.13 & 16.04 & 15.09 & 9.09 \\
\hline Total reads & $\ldots$ & $1,926,284$ & $\ldots$ & $\ldots$ & $24,810,868$ & $\ldots$ & $\ldots$ \\
\hline
\end{tabular}

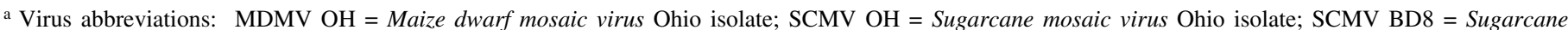
mosaic virus BD8 isolate; SrMV H = Sorghum mosaic virus $\mathrm{H} ; \mathrm{JGMV}=$ Johnsongrass mosaic virus; PenMV = Pennisetum mosaic virus; HoMV = Hordeum mosaic virus; $\mathrm{PVY} \mathrm{OH}=$ Potato virus $Y$ Ohio isolate; MCDV-T, MCDV-M1, MCDV-Tn = Maize chlorotic dwarf virus type, mild and Tennessee isolates; HPV $\mathrm{NP}=$ High Plains virus nucleoprotein segment; MCMV Si = Maize chlorotic mottle virus Sichuan isolate; MCMV NE = Maize chlorotic mottle virus Nebraska isolate; PBV RTase = Pineapple bacilliform virus reverse transcriptase; RsCV-3 = Raphanus sativus cryptic virus 3 segment 1 ; BCV RNA1 = Beet cryptic virus 1 coat protein segment; MSV-A = Maize streak virus A. RNA-Seq reads mapped using mismatch cost, insertion cost, and deletion cost of ' 1 ', length fraction 0.5 and similarity fraction indicated in CLC Genomics Workbench v. 6.0.1 to a subset of 18 virus reference sequences indicated, with random mapping of reads having multiple matches.

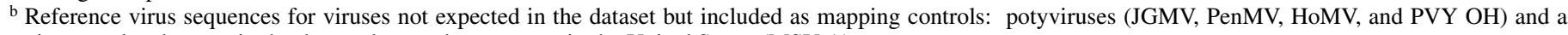
virus unrelated to any in the detected set and not present in the United States (MSV-A). 
and was found in both Johnsongrass and sweet corn in every county sampled. Although MDMV sequences were abundant, they were sufficiently variable that they did not assemble into virus-length contigs or supercontigs. In contrast to MDMV, strong MCDV symptoms were never observed in our field collections. Serology, sequencing, and transmission confirmed the presence of MCDV, predominantly the mild strain MCDV-M1. In addition to the two known major U.S. maize viruses, we confirmed the presence of $\mathrm{WMoV}$, recently reported in Ohio (59), in a single sweet corn sample, and identified the sequence of a putative novel partitivirus in Johnsongrass. Finally, RNA sequences matching SCMV, SrMV, and MCMV were identified. The presence of SCMV was confirmed by PAS-ELISA but none was confirmed by RT-PCR assays.

Comparison of MDMV CP sequences typically used for phylogenetic analyses $(2,3,18)$ indicated limited variability in the $\mathrm{CP}$ sequences in maize or Johnsongrass. The N-terminal sequence of potyviral CPs is hypervariable and, thus, very informative. Interestingly, the field-collected isolates lacked the deletions in the MDMV $\mathrm{OH}$ and SCMV $\mathrm{OH}$ laboratory isolate sequences (MDMV OH-1 and MDMV OH-2, GenBank accession nos. JQ403608 JQ403609, respectively, and SCMV OH, GenBank accession no. JX188485) (58; Redinbaugh et al., unpublished data), suggesting that aphid-free passaging in the laboratory may result in loss of virus $\mathrm{CP}$ sequences that might be important for aphid transmission.

Though far less abundant than MDMV, the sequences matching other potyviruses in the "sugarcane mosaic virus subgroup" in our sample set are of interest. MDMV, SCMV, and SrMV all belong to the sugarcane mosaic virus subgroup within the virus genus Potyvirus, family Potyviridae $(53,54)$. Although Potyvirus spp. typically have $\leq 80 \%$ identity across the genome, strains within a species have close to 85 to $90 \%$ sequence identity where complete genomes are available (6). Our detection of SCMV in both maize and Johnsongrass was very surprising, given that SCMV is only expected to infect maize (23). SCMV was initially distinguished from MDMV as the "nonjohnsongrass strain" of the related potyviruses (23), and is most prevalent in northern Ohio, whereas MDMV is prevalent in the south, corresponding to Johnsongrass distribution. The overwintering host of SCMV has not been identified (1). SCMV contigs fell into two distinct categories, most similar to either SCMV OH (Redinbaugh et al., unpublished data) or SCMV-BD8 (17) sequences, which are $90 \%$ identical to each other. The SCMV BD8 CP sequence groups with SCMV sequences of isolates and sugarcane from Hebei in China, Thailand, and Vietnam (33). SrMV-like sequences were also identified in both maize and Johnsongrass. SrMV causes mosaic symptoms similar to MDMV and SCMV, and is a disease problem primarily on sorghum and sugarcane. It has been reported previously in the United States (22), China (27), and India (30). Potyvirus contigs analyzed here consistently matched only one species in blast searches but, because we were not able to detect SCMV or SrMV RNA by RT-PCR and detected sequences were low-abundance, their importance it is not clear.

MCDV, the second major U.S. maize virus, was also detected in Johnsongrass but rarely in maize. Notably, collections were made before leafhopper populations and maize inoculation were expected to be high (37). Symptom selection may have also contributed to low MCDV detection, given our finding that the mild (nearly asymptomatic) strain was predominant, and because even strongly symptomatic MCDV may be asymptomatic in Johnsongrass. Unlike potyviruses, very few sequences of viruses in the genus Waikavirus, including MCDV, are reported. We expected to find additional MCDV sequence variability but found only two genome-length sequences nearly identical to previously determined sequences of MCDV-T (38) and MCDV-M1 (R. Gingery et al., unpublished data) from Ohio. Additional divergent MCDV sequences have been described from two other locations, including the complete genome of a Tennessee isolate and $860 \mathrm{nt}$ of MCDV-like sequences from Oklahoma $(47,61)$. Reported MCDV disease in maize followed distribution of overwintering Johnsongrass, which was introduced to the United States in approximately the early 1800s (39). It may be that Ohio MCDV represents a subset of the virus population but further information on waikaviruses is needed to understand its origins and diversity. To date, MCDV is only reported in the United States.

WMoV, the causal agent of High Plains disease in wheat and maize, was confirmed by ELISA and RT-PCR (data not shown) in a single maize plant in Scioto County, on the southern edge of Ohio. WMoV was recently reported in Ohio wheat in western counties (59). WMoV has potential to become problematic where wheat and corn are grown in adjacent locations with transmitting populations of wheat curl mite (Aceria tosichella). In addition to WMoV, we identified a single contig matching MCMV. However, repeated RT-PCR tests failed to detect MCMV in our samples. MCMV can cause maize lethal necrosis in combination with any virus in the family Potyviridae (42), which is a sporadic disease problem reported in Kansas and Nebraska $(42,56)$ and a major emerging disease in east Africa (64).

We detected a putative new partitivirus in Johnsongrass. Viruses in the family Partitiviridae are bipartite double-stranded (ds)RNA viruses encoding an RdRP and a capsid protein on separate genomic RNAs, each $\approx 2 \mathrm{~kb}$ (12). Plant partitivirus dsRNAs are encapsidated but only transmitted by pollen and seed, and infections are generally asymptomatic (12). Genera within the family Partitiviridae have recently been redefined $(19,41)$, and the confirmed sequence identified most closely matches viruses in the new genus Deltapartitivirus. Viruses in the family Partitiviridae have been described in fungi and protozoans as well as in plants. Only two grass-infecting partitiviruses have been reported to date, with sequence data only from a recent report of a putative Thin papsalum cryptic virus (52), to which our sequences show no identity by blastn.

Deep sequencing for plant virus discovery is becoming increasingly common. Most studies use small RNA sequencing to limit the number of input sequences and to select for virus sequences rather than sorting through the host organism mRNA to find virus sequences $(9,11,15,31,32,43)$. Complete virus genomes can be assembled using this approach; however, assembly of short sequence reads of $\approx 20$ to $25 \mathrm{nt}$ requires sophisticated bioinformatics. Others have enriched for viral RNA by extracting dsRNA $(8,9,14,50)$ or selecting mRNAs $(7,66,67)$. Our approach was slightly different, assembling the entire poly-A selected RNA sequence set de novo. Not all viral RNAs are polyadenylated; therefore, this approach biased sequences toward viruses that are, such as MCDV and MDMV. More and longer sequence reads are assembled using this approach than short-read sequencing but it then requires removal of abundant nonviral sequence contigs. Based on our estimates, 6 to $16 \%$ of processed reads from symptomatic plants were of putative viral origin, consistent with read percentages observed by others (67). Identification of viruses using any deep-sequencing approach relies on finding sequence matches to known viruses and, therefore, is constrained by limitations and annotation quality of the current databases.

In conclusion, serological tests and RNA-Seq demonstrated the presence of MDMV, MCDV, and several other viruses in Ohio maize and Johnsongrass. Results indicated that management has been successful in controlling these viruses in field corn, because they were very rarely detected in this crop. However, viruses remain in Johnsongrass and continue to cause diseases in sweet corn. Additional studies are needed to examine the current incidence and economic impact of virus disease in detail. Based on the persistence of virus reservoirs, virus management practices such as planting resistant cultivars and controlling Johnsongrass are still advisable for sweet corn. 


\section{ACKNOWLEDGMENTS}

We thank A. Dorrance (Ohio State University) for use of her CLC Genomics software and computing platform, R. Louie (United States Department of Agriculture-Agricultural Research Service [USDA-ARS], retired) for helpful discussion and identifying sites of original MCDV and MDMV isolate collection circa 1970, and C. Nacci (USDA-ARS) and E. Umanzor for assisting with sample collection and detection assays.

\section{LITERATURE CITED}

1. Abt, J. J. 1983. Epidemiology of maize dwarf mosaic in northern Ohio sweet corn. M.S. thesis, Ohio State University, Wooster.

2. Achon, M. A., Alonso-Duenas, N., and Serrano, L. 2011. Maize dwarf mosaic virus diversity in the Johnsongrass native reservoir and in maize: Evidence of geographical, host and temporal differentiation. Plant Pathol. 60:369-377.

3. Achon, M. A., Larranaga, A., and Alonso-Duenas, N. 2012. The population genetics of Maize dwarf mosaic virus in Spain. Arch. Virol. 157:2377-2382.

4. Adams, I. P., Glover, R. H., Monger, W. A., Mumford, R., Jackeviciene, E., Navalinskiene, M., Samuitiene, M., and Boonham, N. 2009. Nextgeneration sequencing and metagenomic analysis: A universal diagnostic tool in plant virology. Mol. Plant Pathol. 10:537-545.

5. Adams, I. P., Miano, D. W., Kinyua, Z. M., Wangai, A. W., Kimani, E., Phiri, N., Reeder, R., Harju, V., Glover, R., Hany, U., Souza-Richards, R., Deb Nath, P., Nixon, T., Fox, A., Barnes, A., Smith, J., Skelton, A., Thwaites, R., Mumford, R., and Boonham, N. 2012. Use of nextgeneration sequencing for the identification and characterization of Maize chlorotic mottle virus and Sugarcane mosaic virus causing maize lethal necrosis in Kenya. Plant Pathol. 62:741-749

6. Adams, M. J., Antoniw, J. F., and Fauquet, C. M. 2005. Molecular criteria for genus and species discrimination within the family Potyviridae. Arch. Virol. 150:459-479.

7. Alabi, O. J., Zheng, Y., Jagadeeswaran, G., Sunkar, R., and Naidu, R. A. 2012. High-throughput sequence analysis of small RNAs in grapevine (Vitis vinifera L.) affected by grapevine leafroll disease. Mol. Plant Pathol. 13:1060-1076.

8. Al Rwahnih, M., Daubert, S., Golino, D., and Rowhani, A. 2009. Deep sequencing analysis of RNAs from a grapevine showing Syrah decline symptoms reveals a multiple virus infection that includes a novel virus. Virology 387:395-401.

9. Al Rwahnih, M., Daubert, S., Urbez-Torres, J. R., Cordero, F., and Rowhani, A. 2011. Deep sequencing evidence from single grapevine plants reveals a virome dominated by mycoviruses. Arch. Virol. 156:397403.

10. Altschul, S. F., Gish, W., Miller, W., Myers, E. W., and Lipman, D. J. 1990. Basic local alignment search tool. J. Mol. Biol. 215:403-410.

11. Bi, Y. Q., Tugume, A. K., and Valkonen, J. P. T. 2012. Small-RNA Deep sequencing reveals Arctium tomentosum as a natural host of Alstroemeria virus $X$ and a new putative emaravirus. PLoS One. doi:10.1371/ journal.pone. 0042758

12. Boccardo, G., Lisa, V., Luisoni, E., and Milne, R. G. 1987. Cryptic plant viruses. Adv. Virus Res. 32:171-214.

13. Chaouch, R., Redinbaugh, M. G., Marrakchi, M., and Hogenhout, S. A. 2004. Genomics of the severe isolate of Maize chlorotic dwarf virus. Plant Prot. Sci. 40:113-119.

14. Coetzee, B., Freeborough, M. J., Maree, H. J., Celton, J. M., Rees, D. J. G., and Burger, J. T. 2010. Deep sequencing analysis of viruses infecting grapevines: Virome of a vineyard. Virology 400:157-163.

15. Donaire, L., Wang, Y., Gonzalez-Ibeas, D., Mayer, K. F., Aranda, M. A., and Llave, C. 2009. Deep-sequencing of plant viral small RNAs reveals effective and widespread targeting of viral genomes. Virology 392:203214.

16. Edwards, M. L., and Cooper, J. I. 1985. Plant-virus detection using a new form of indirect ELISA. J. Virol. Methods 11:309-319.

17. Gao, B., Cui, X. W., Li, X. D., Zhang, C. Q., and Miao, H. Q. 2011. Complete genomic sequence analysis of a highly virulent isolate revealed a novel strain of Sugarcane mosaic virus. Virus Genes 43:390-397.

18. Gell, G., Balazs, E., and Petrik, K. 2010. Genetic diversity of Hungarian Maize dwarf mosaic virus isolates. Virus Genes 40:277-281.

19. Ghabrial, S. A., Nibert, M. L., Maiss, E., Lesker, T., Baker, T. S., and Tao, Y. J. 2012. Family Partitiviridae. Pages 523-534 in: Virus Taxonomy: Ninth Report of the International Committee on Taxonomy of Viruses. A. M. Q. King, M. J. Adams, E. B. Carstens, and E. J. Lefkowitz, eds. Elsevier, San Diego, CA.

20. Giampetruzzi, A., Roumi, V., Roberto, R., Malossini, U., Yoshikawa, N., La Notte, P., Terlizzi, F., Credi, R., and Saldarelli, P. 2012. A new grapevine virus discovered by deep sequencing of virus- and viroid- derived small RNAs in cv. Pinot Gris. Virus Res. 163:262-268.

21. Gingery, R. E., and Nault, L. R. 1990. Severe maize chlorotic dwarf disease caused by double infection with mild virus-strains. Phytopathology 80:687-691.

22. Giorda, L. M., Toler, R. W., and Miller, F. R. 1986. Identification of Sugarcane mosaic-virus strain-H isolate in commercial grain-sorghum. Plant Dis. 70:624-628.

23. Gordon, D. T., Bradfute, O. E., Gingery, R. E., Knoke, J. K., and Nault, L. R. 1978. Maize virus disease complexes in the United States: Real and potential disease problems. Pages 102-133 in: 33rd Annu. Corn Sorghum Res. Conf. Ohio Agric. Res. Dev. Center, Wooster.

24. Hunt, R. E., Nault, L. R., and Gingery, R. E. 1988. Evidence for infectivity of maize chlorotic dwarf virus and for a helper component in its leafhopper transmission. Phytopathology 78:499-504.

25. Janson, B. F., and Ellett, C. W. 1963. A new corn disease in Ohio. Plant Dis. Rep. 47:1107-1108.

26. Jensen, S. G. 1992. A viewpoint on the taxonomy of potyviruses infecting sugarcane, maize, and sorghum. Arch. Virol. S5(Suppl.):349-351.

27. Jiang, J. X., and Zhou, X. P. 2002. Maize dwarf mosaic disease in different regions of China is caused by Sugarcane mosaic virus. Arch. Virol. 147:2437-2443.

28. Kerns, M. R., and Pataky, J. K. 1997. Reactions of sweet corn hybrids with resistance to maize dwarf mosaic. Plant Dis. 81:460-464.

29. Knoke, J. K., Louie, R., Madden, L. V., and Gordon, D. T. 1983. Spread of maize-dwarf mosaic-virus from Johnsongrass to corn. Plant Dis. 67:367-370.

30. Kondaiah, E., and Nayudu, M. V. 1984. Sugarcane mosaic-virus strain $\mathrm{H}-\mathrm{a}$ new record from India. Curr. Sci. India 53:273-275.

31. Kreuze, J. F., Perez, A., Untiveros, M., Quispe, D., Fuentes, S., Barker, I., and Simon, R. 2009. Complete viral genome sequence and discovery of novel viruses by deep sequencing of small RNAs: A generic method for diagnosis, discovery and sequencing of viruses. Virology 388:1-7.

32. Li, R. G., Gao, S., Hernandez, A. G., Wechter, W. P., Fei, Z. J., and Ling, K. S. 2012. Deep sequencing of small RNAs in tomato for virus and viroid identification and strain differentiation. PLoS One 7:e37127. doi:10.1371/journal.pone.0037127

33. Li, Y. Q., Liu, R. Y., Zhou, T., and Fan, Z. F. 2013. Genetic diversity and population structure of Sugarcane mosaic virus. Virus Res. 171:242-246.

34. Lopes, J. R. S., Nault, L. R., and Gingery, R. E. 1994. Leafhopper transmission and host-plant range of maize chlorotic dwarf waikavirus strains. Phytopathology 84:876-882.

35. Louie, R. 1995. Vascular puncture of maize kernels for the mechanical transmission of maize white line mosaic-virus and other viruses of maize. Phytopathology 85:139-143.

36. Louie, R., and Knoke, J. K. 1975. Strains of maize-dwarf mosaic-virus. Plant Dis. Rep. 59:518-522.

37. Louie, R., Knoke, J. K., and Gordon, D. T. 1974. Epiphytotics of maizedwarf mosaic and maize chlorotic dwarf diseases in Ohio. Phytopathology 64:1455-1459.

38. McMullen, M. D., Roth, B. A., and Townsend, R. 1996. Maize chlorotic dwarf virus and resistance thereto. U.S. Patent number 5569828.

39. McWhorter, C. G. 1971. Introduction and spread of Johnsongrass in United States. Weed Sci. 19:496-500.

40. Mikel, M. A., Darcy, C. J., and Ford, R. E. 1984. Seed transmission of maize-dwarf mosaic-virus in sweet corn. Phytopathol. Z. 110:185-191.

41. Nibert, M. L., Ghabrial, S. A., Maiss, E., Lesker, T., Vainio, E. J., Jiang, D., and Suzuki, N. 2014. Taxonomic reorganization of family Partitiviridae and other recent progress in partitivirus research. Virus Res. 188C:128-141.

42. Niblett, C. L., and Claflin, L. E. 1978. Corn lethal necrosis-new virusdisease of corn in Kansas. Plant Dis. Rep. 62:15-19.

43. Pantaleo, V., Saldarelli, P., Miozzi, L., Giampetruzzi, A., Gisel, A., Moxon, S., Dalmay, T., Bisztray, G., and Burgyan, J. 2010. Deep sequencing analysis of viral short RNAs from an infected Pinot Noir grapevine. Virology 408:49-56.

44. Pereira, A. J., Alfenas-Zerbini, P., Cascardo, R. S., Andrade, E. C., and Zerbini, F. M. 2012. Analysis of the full-length genome sequence of Papaya lethal yellowing virus (PLYV), determined by deep sequencing, confirms its classification in the genus Sobemovirus. Arch. Virol. 157:2009-2011.

45. Petrik, K., Sebestyen, E., Gell, G., and Balazs, E. 2010. Natural insertions within the N-terminal region of the coat protein of Maize dwarf mosaic potyvirus (MDMV) have an effect on the RNA stability. Virus Genes 40:135-139.

46. Radford, A. D., Chapman, D., Dixon, L., Chantrey, J., Darby, A. C., and Hall, N. 2012. Application of next-generation sequencing technologies in virology. J. Gen. Virol. 93:1853-1868.

47. Reddick, B. B., Habera, L. F., and Law, M. D. 1997. Nucleotide sequence and taxonomy of maize chlorotic dwarf virus within the family Sequiviridae. J. Gen. Virol. 78:1165-1174. 
48. Redinbaugh, M. G., Jones, M. W., and Boyd, E. C. 2011. Responses of maize (Zea mays L.) near isogenic lines carrying Wsm1, Wsm2 and Wsm3 to three viruses in the Potyviridae. Phytopathology 101:S151-S151.

49. Redinbaugh, M. G., and Pratt, R. C. 2008. Virus resistance. Pages 255270 in: Maize Handbook. S. Hake and J. Bennetzen, eds. Springer-Verlag, New York.

50. Roossinck, M. J., Saha, P., Wiley, G. B., Quan, J., White, J. D., Lai, H., Chavarria, F., Shen, G. A., and Roe, B. A. 2010. Ecogenomics: Using massively parallel pyrosequencing to understand virus ecology. Mol. Ecol. 19:81-88.

51. Rosenkranz, E. 1969. A new leafhopper-transmissible corn stunt disease agent in Ohio. Phytopathology 59:1344-1346.

52. Scheets, K. 2013. Infectious transcripts of an asymptomatic panicovirus identified from a metagenomic survey. Virus Res. 176:161-168.

53. Shukla, D. D., Frenkel, M. J., McKern, N. M., Ward, C. W., Jilka, J., Tosic, M., and Ford, R. E. 1992. Present status of the sugarcane mosaic subgroup of potyviruses. Arch. Virol. Suppl. 5:363-373.

54. Shukla, D. D., Tosic, M., Jilka, J., Ford, R. E., Toler, R. W., and Langham, M. A. C. 1989. Taxonomy of potyviruses infecting maize, sorghum, and sugarcane in Australia and the United States as determined by reactivities of polyclonal antibodies directed towards virus-specific N-termini of coat proteins. Phytopathology 79:223-229.

55. Skare, J. M., Wijkamp, I., Denham, I., Rezende, J. A. M., Kitajima, E. W., Park, J. W., Desvoyes, B., Rush, C. M., Michels, G., Scholthof, K. B. G., and Scholthof, H. B. 2006. A new eriophyid mite-borne membraneenveloped virus-like complex isolated from plants. Virology 347:343-353.

56. Stenger, D. C., and French, R. 2008. Complete nucleotide sequence of a Maize chlorotic mottle virus isolate from Nebraska. Arch. Virol. 153:995-997.

57. Stewart, L. R. 2011. Waikaviruses: Studied but not understood. APSnet feature. www.apsnet.org/publications/apsnetfeatures/Pages/waikavirus.aspx

58. Stewart, L. R., Bouchard, R., Redinbaugh, M. G., and Meulia, T. 2012. Complete sequence and development of a full-length infectious clone of an Ohio isolate of Maize dwarf mosaic virus (MDMV). Virus Res. 165:219-224.

59. Stewart, L. R., Paul, P. A., Qu, F., Redinbaugh, M. G., Miao, H. Q., Todd, J. C., and Jones, M. W. 2013. Wheat mosaic virus (WMoV), the causal agent of High Plains disease, is present in Ohio wheat fields. Plant Dis. $97: 1125$.
60. Sutula, C. L., Gillett, J. M., Morrissey, S. M., and Ramsdell, D. C. 1986. Interpreting ELISA data and establishing the positive-negative threshold. Plant Dis. 70:722-726.

61. Thapa, V., Melcher, U., Wiley, G. B., Doust, A., Palmer, M. W., Roewe, K., Roe, B. A., Shen, G. A., Roossinck, M. J., Wang, Y. M., and Kamath, N. 2012. Detection of members of the Secoviridae in the Tallgrass Prairie Preserve, Osage County, Oklahoma, USA. Virus Res. 167:34-42.

62. Tobias, I., and Palkovics, L. 2004. An unusual feature at the N-terminal end of the coat protein of Maize dwarf mosaic virus isolated in Hungary. J. Phytopathol. 152:445-447.

63. Uzarowska, A., Dionisio, G., Sarholz, B., Piepho, H. P., Xu, M. L., Ingvardsen, C. R., Wenze, G., and Lubberstedt, T. 2009. Validation of candidate genes putatively associated with resistance to SCMV and MDMV in maize (Zea mays L.) by expression profiling. BMC Plant Biol. 9:15. doi:10.1186/1471-2229-9-15

64. Wangai, A. W., Redinbaugh, M. G., Kinyua, Z. M., Miano, D. W., Leley, P. K., Kasina, M., Mahuku, G., Scheets, K., and Jeffers, D. 2012. First report of Maize chlorotic mottle virus and maize lethal necrosis in Kenya. Plant Dis. 96:1582-1583.

65. Wu, Q. F., Luo, Y. J., Lu, R., Lau, N., Lai, E. C., Li, W. X., and Ding, S. W. 2010. Virus discovery by deep sequencing and assembly of virusderived small silencing RNAs. Proc. Natl. Acad. Sci. USA 107:16061611.

66. Wylie, S. J., and Jones, M. G. K. 2011. The complete genome sequence of a Passion fruit woodiness virus isolate from Australia determined using deep sequencing, and its relationship to other potyviruses. Arch. Virol. 156:479-482.

67. Wylie, S. J., Luo, H., Li, H., and Jones, M. G. K. 2012. Multiple polyadenylated RNA viruses detected in pooled cultivated and wild plant samples. Arch. Virol. 157:271-284.

68. Yan, F., Zhang, H. M., Adams, M. J., Yang, J., Peng, J. J., Antoniw, J. F., Zhou, Y. J., and Chen, J. P. 2010. Characterization of siRNAs derived from Rice stripe virus in infected rice plants by deep sequencing. Arch. Virol. 155:935-940.

69. Yang, Z. N., and Mirkov, T. E. 1997. Sequence and relationships of sugarcane mosaic and sorghum mosaic virus strains and development of RT-PCR-based RFLPs for strain discrimination. Phytopathology 87:932939. 